\title{
Design and Operation of Small-Scale Photovoltaic-Driven Reverse Osmosis (PV-RO) Desalination Plant for Water Supply in Rural Areas
}

\author{
Fawzi Banat ${ }^{1}$, Hazim Qiblawey ${ }^{2}$, Qais Al-Nasser ${ }^{3}$ \\ ${ }^{1}$ Department of Chemical Engineering, The Petroleum Institute, Abu Dhabi, United Arab Emirates \\ ${ }^{2}$ Department of Chemical Engineering, Qatar University, Doha, Qatar \\ ${ }^{3}$ Department of Chemical Engineering, Jordan University of Science and Technology, Irbid, Jordan \\ Email: fbanat@pi.ac.ae
}

Received August 30, 2012; revised September 3, 2012; accepted October 10, 2012

\begin{abstract}
The alarming water and energy crisis in many regions of the world can be eased by combining renewable energy with desalination technologies. The ADIRA project funded by the EU looked for demonstrating the feasibility of water desalination in areas around the Mediterranean by installing a number of autonomous desalination systems (ADS) which are able to convert brackish or seawater into potable water for the needs of small communities. Within the activities of the ADIRA project a reverse osmosis unit powered by photovoltaic electricity was installed in a village in the northern part of Jordan with a capacity of $0.5 \mathrm{~m}^{3} /$ day. The system was composed of a softener, reverse osmosis unit, PV panels (432 Wp) and storage batteries. Residential type "OSMONICS" membrane (TFM-100) was utilized in the RO unit. Field tests were performed on brackish water $(1700 \mathrm{mg} / \mathrm{L}$ total dissolved solids (TDS)). This paper sheds the light on the process flow diagram, sizing of the system main components and presents some of the results obtained.
\end{abstract}

Keywords: Reverse Osmosis; Water Filters; Ion Exchange System; Membranes; Carbon Filters

\section{Introduction}

Small capacity desalination units utilizing the reverse osmosis (RO) technology and powered by photovoltaic (PV) cells, is a potential solution for providing freshwater to small comminutes in isolated arid areas that have 1) saline water problems; 2) no access to the electricity grid; and 3) plenty solar resources. PVRO has minimal environmental impact, can be easily designed and assembled for different demand profiles using modular components [1], and can be easily maintained and repaired.

Options of PV-RO configurations are available to overcome the intermittent nature of solar power, these are: 1) Use of fossil fuel to make up the gaps (grid-connected systems), 2) store the solar energy, 3) run the desalination plant intermittently. Systems without a grid-connection are generally described as standalone or autonomous systems.

Numerous renewable energy-powered RO plants, primarily PV-battery systems of small to medium capacity ( 0.5 to $50 \mathrm{~m}^{3} /$ day), have been built in different locations of the world. For example, Herold and Neskakis [2] presented a small PV-driven reverse osmosis desalination plant on the island of Gran Canaria with an average daily drinking water production of $0.8-3 \mathrm{~m}^{3} / \mathrm{d}$. The plant was supplied by a stand-alone $4.8 \mathrm{kWp}$ photovoltaic (PV) system with additional battery storage of $60 \mathrm{kWh}$. The nominal production was $1 \mathrm{~m}^{3} /$ day. The specific energy consumption of this system was considered high with 16 $\$ / \mathrm{m}^{3}$ production cost.

The Energy Research Institute of King Abdulaziz City for Science and Technology (KACST) conducted extensive research on a PV-battery-inverter RO system in Sadous, Saudi Arabia. The RO system produced on average $5.7 \mathrm{~m}^{3} /$ day, converting brackish water from $5700 \mathrm{ppm}$ TDS to $170 \mathrm{ppm}$ TDS with an average $30 \%$ recovery rate [3].

In 2001 Solar Energy Systems (SES) in Australia worked on commercializing a PV-RO unit, developed at Murdoch University, that is capable of producing 100 gallons per day of water from feed water containing up to 5000 ppm TDS [4]. They installed approximately 20 systems, primarily in the desert area of Australia. The system was designed for 15 to 20 percent water recovery. Part of the reasoning for the low water recovery was to reduce problems with scaling.

Carvalho et al. [5] presented the cost of PV-RO desalination plant with batteries installed in the community of Ceara, of Brazil. The specific energy consumption of 
produced water was around $3.03 \mathrm{kWh} / \mathrm{m}^{3}$ with cost of $12.76 \$ / \mathrm{m}^{3}$.

Riffel and Carvalho [6] presented a small-scale batteryless PV-RO plant for stand-alone applications that operates at variable flow/pressure conditions in equatorial areas to desalinate brackish water.

Mohamed et al. [7] presented the experimental results of a small seawater RO system, installed at the University of Athens, equipped with an ERD of the Clark pump type.

Qiblawey et al. [8] presented experimental results of a PV powered household RO unit installed in Jordan and operated with tap water having $350 \mathrm{mg} / \mathrm{L}$ and $720 \mathrm{mg} / \mathrm{L}$ total dissolved solids. The unit was operated with and without storage batteries. The specific energy consumption of the battery system ranged from $1.1 \mathrm{kWh} / \mathrm{m}^{3}$ to 4.3 $\mathrm{kWh} / \mathrm{m}^{3}$ and ranged from $1.1 \mathrm{kWh} / \mathrm{m}^{3}$ to $1.5 \mathrm{kWh} / \mathrm{m}^{3}$ for the battery-less system.

In the context of ADIRA project a PV-RO unit with production capacity of $0.5 \mathrm{~m}^{3} /$ day was designed and installed in a village in the northern part of Jordan. The ADIRA project is one of the MEDA projects financially supported by the European Union (EU) for the development of the water sector in the Middle Eastern and North African (MENA) countries. This paper presents sizing of the unit components along with some results.

\section{Method}

\subsection{Process flow diagram}

The process flow diagram of the PV-RO system is shown in Figure 1. The system has three major components, a PV array, a spiral wound membrane module, and a softener. The softener treats raw water from mineral ions that cause scaling problems. The pretreatment step consists of 4 stages: Softener, 5 Micron sediment filter, granular activated carbon filter (GAC) and 1 Micron sidemen filter. The system was fed with untreated brackish water with a salinity of $1700 \mathrm{mg} / \mathrm{L}$. In these experiments, four residential membrane modules "OSMONICS” type (TFM-100) were utilized. Electricity needed by the system was partially supplied by the PV array which consists from $8 \mathrm{PV}$ modules each $54 \mathrm{Wp}$. Since the RO unit needs a stable power supply, two batteries $(12 \mathrm{~V}, 230 \mathrm{Ah})$ were connected in series to increase the voltage up to $24 \mathrm{~V}$. The energy produced by the PV is transferred through the solar charge regulator to battery storage capable of storing enough energy for extra operation hours after sunset. The stored energy is transferred back to regulator unit for powering the loads.

Solar charge controller was used to connect PV panels to storage batteries. Charge controllers block reverse current and prevent battery overcharge. Also prevent battery over discharge, protect from electrical overload, and display battery status. Its purpose is to keep batteries and loads properly fed and safe for the long term. A series of temperature sensors (Pico Technology, UK) were installed throughout the system in order to measure the temperature of ambient, feed water, and the PV panels. Two flow meters (FLR1000, USA) were installed to measure the volumetric flow rate of raw water feed and permeate. A pressure sensor (Omega PX309, USA) was installed in the feed stream to control the pressure of the feed pump. TDS probes (HMDigital, USA) were installed in the feed stream and in the permeate stream in order to measure the quality of fed and treated water. A pyranometer (PYR-PA2.5, USA) was installed to measure the global irradiation during the operation time. Two clamps meter (Pico Technology, UK) were installed to measure the available current from PV and to measure the charger current of batteries.

The rechargeable batteries used aimed mainly for storing energy during the day to make it available through nights to ensure continuous operation. Figure 2 shows illustrative block diagram of the PV-RO system. The system was tested for about 10 months; the aim of the system testing was to investigate the water production quantity and quality as well as the specific energy consumption of the unit under different operating conditions.

\subsection{Sizing of the System}

\subsubsection{Daily Energy Requirement}

The total daily energy requirements for the RO unit, softener unit and the auxiliaries (sensors, data acquisition system etc.) have been determined as follows:

\subsubsection{RO Load}

Two high pressure pumps (HPP): Volts $=24$ VDC, Maximum current $=1.2 \mathrm{~A}$

Power of one HPP $=24 * 1.2=28.8 \mathrm{~W}$

Total Power $=28.8 * 2=57.6 \mathrm{~W}$

Hours of operation (average per day) $=8 \mathrm{~h}$

Total RO energy required/day $=57.6 * 8=460.8 \mathrm{Wh}$

\subsubsection{Intake Pump}

Intake pump: Volts $=220 \mathrm{VAC}, 50 \mathrm{~Hz}$, Current $=0.54 \mathrm{~A}$, Output power $=60 \mathrm{~W}$

Load including inverter losses (assuming the inverter losses $\left(\eta_{\text {inv }}\right)$ to be about $10 \%=60 / 0.9=66.7 \mathrm{~W}$

Hours of operation $=8 \mathrm{~h}$

Total energy required/day $=66.7 * 8=533.3 \mathrm{Wh}$

\subsubsection{Softener Feed Pump}

Softener pump: Volts $=230 \mathrm{VAC}, 50 \mathrm{~Hz}$, Current $=6.2$

A, Output power $=1.0 \mathrm{hp}$

Power of Softener pump $=1 \mathrm{hp}=746 \mathrm{~W}$ 


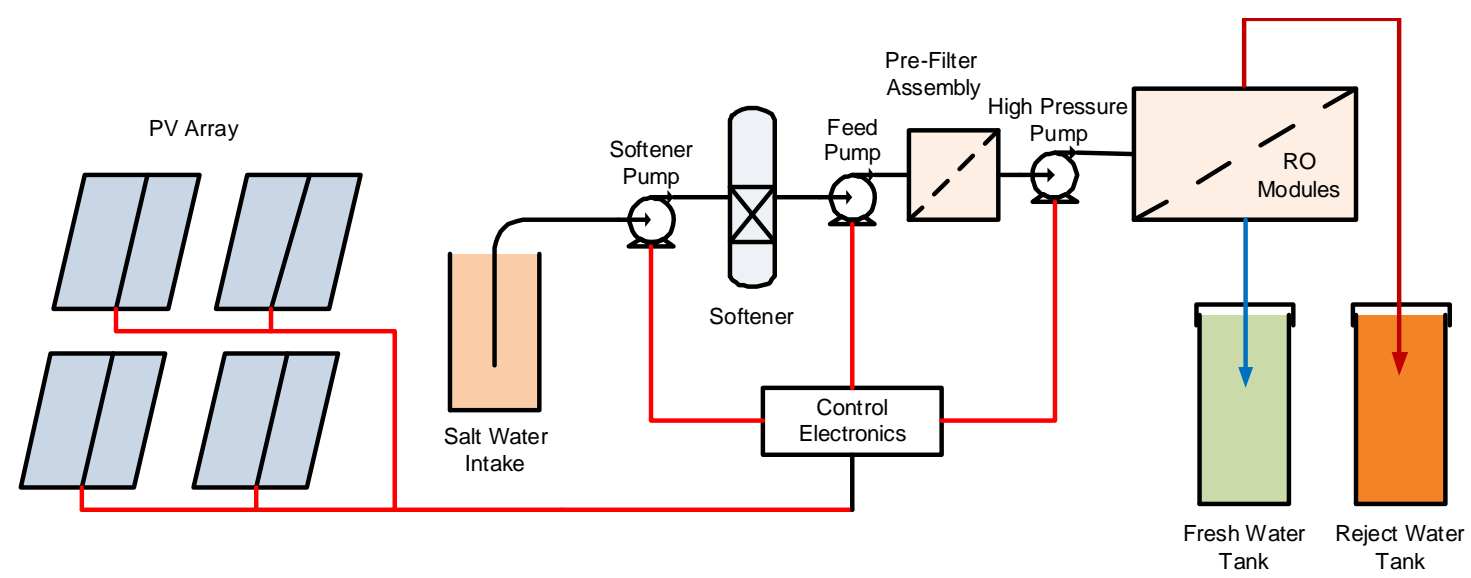

Figure 1. Process flow diagram.

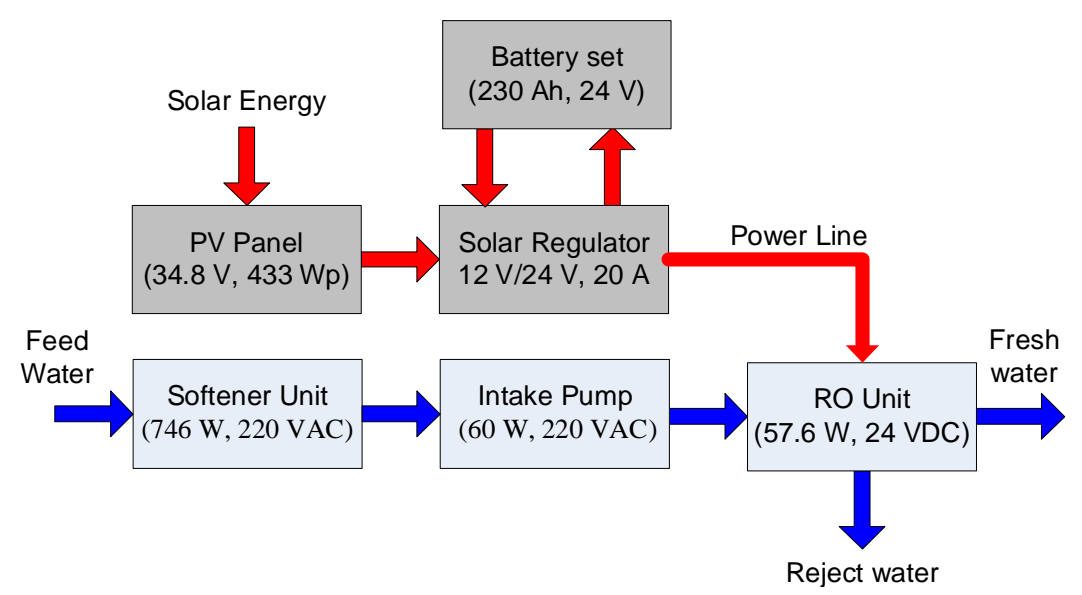

Figure 2. Block diagram of the system.

Load including inverter losses $=746 / 0.9=828.9 \mathrm{~W}$

Hours of operation $=8 \mathrm{~h}$

Total energy required/day $=828.9 * 8=6631.2 \mathrm{Wh}$

\subsubsection{Auxiliaries Load}

Data acquisition system including sensors: Volts $=10$

VDC, Current $=100-500 \mathrm{~mA}$.

Maximum Power $=0.5 \mathrm{~A} * 10 \mathrm{~V}=5 \mathrm{~W}$

Hours of operation $=24 \mathrm{~h}$

Total Auxiliaries energy required/day $=5 * 24=120$ Wh

Solar charge regulator: Volts $=24$ VDC, Current $=15.8$ $\mathrm{mA}$

Maximum Power $=0.0158 \mathrm{~A} * 24 \mathrm{~V}=0.38 \mathrm{~W}$

Hours of operation $=24 \mathrm{~h}$

Total energy required/day $=0.38 * 24=9.1 \mathrm{Wh}$

The daily energy required including the losses for inverters $=460.8+533.3+6631.2+120+9.1=7754.4$ Wh/day.

\subsubsection{PV Panels}

The theoretical daily energy requirement for the system is about $7.754 \mathrm{kWh} /$ day $\left(E_{L}\right)$, including the inverter losses.

The battery losses $\left(\eta_{b}\right)$ is about $15 \%$ [9] and the PV thermal losses $\left(\eta_{t h}\right)$ is about 15\% [9] also. The average peak sunshine hour (PSSH) in Jordan is about $7 \mathrm{~h}$. The peak power of the PV module can be determined as follows:

$$
\begin{aligned}
\text { Peak power of the PV } & =\mathrm{E}_{\mathrm{L}} /\left(\mathrm{PSSH} \times \eta_{\mathrm{th}} \times \eta_{\mathrm{b}}\right) \\
& =7.754 /(7 \times 0.85 \times 0.85) \\
& =1.533 \mathrm{KW}_{p}
\end{aligned}
$$

The size of PV module must be such as to produce $1.533 \mathrm{~kW}$ with operating voltage more than $24 \mathrm{~V}$, in order to charge the batteries. Commercially available PV modules of polycrystalline silicon type of $54 \mathrm{Wp}$ as peak power were selected $\left(I_{S C}=3.31 \mathrm{~A}, V_{O C}=21.7 \mathrm{~V}, I_{m}=\right.$ $3.11 \mathrm{~A}, V_{m}=17.4 \mathrm{~V}$ at STC). The system needs approximately $30(1533 / 54) \mathrm{PV}$ modules in order to cover the daily energy requirements. Considering that the DC side operating voltage of $24 \mathrm{~V}$, then $2 \mathrm{PV}$ modules in series are required $(2 * 17.4=34.8 \mathrm{~V})$. These $(2 \mathrm{PV}$ 
modules in series) have to be organized in sub-arrays of 15 parallel strings $(15 * 3.11 \mathrm{~A}=46.65 \mathrm{~A})$, each string connected to the charge controller. The total array peak power is $(3.11 \mathrm{~A} * 17.4 \mathrm{~V}) *(2 * 15)=1.623 \mathrm{kWp}$.

In the initial design of the PV modules; only the energy required for high pressure pumps as well as the auxiliaries were considered with 24 hours of operation ( $\{(2 *$ $24 \mathrm{~V} * 1.2 \mathrm{~A})+(5 \mathrm{~W}+0.38 \mathrm{~W})\} * 24=1511.52$ Wh/day). Intake pump and the softener pump were installed later to improve the operational efficiency of the RO unit, and they were powered directly from the electricity grid, not from the PV array. The desired peak power of the PV module based on the new consideration is about $350 \mathrm{Wp}(1511.52 /(6 * 0.85 * 0.85))$, the average peak sunshine of $6 \mathrm{~h}$ is used to be on the safe side.

The PV array of the system consists of 4 parallel strings each of 2 series PV modules, the total array peak power of the system is $432.9 \mathrm{Wp}((3.11 * 17.4) *(2 * 4))$ which covers the amount of energy required.

\subsubsection{Battery Storage}

The battery of the PV-RO system was designed to act as energy storage to run the system whenever insufficient solar irradiation is available (cloudy days and nights). If $80 \%$ [9] maximum depth of discharge (DOD) is considered, the required maximum battery capacity per day is calculated as follows:

$$
\text { Battery capacity } \begin{aligned}
(\mathrm{Wh}) & =\mathrm{E}_{\mathrm{L}} /\left(\mathrm{DOD} \times \eta_{\mathrm{b}}\right) \\
& =1511.52 /(0.8 \times 0.85) \\
& =2223 \mathrm{Wh}
\end{aligned}
$$

Two batteries of 2760 Wh (230 Ah * $12 \mathrm{~V}$ ) connected in series were selected, producing $5520 \mathrm{Wh}$ (230 Ah * 24 $\mathrm{V}$ ) in total. The battery storage was able to operate the RO unit for more than 59 h continually.

$$
\begin{aligned}
\operatorname{DOA}(\text { day }) & =\left(\text { Battery capacity }(\mathrm{Wh}) \times \mathrm{DOD} \times \eta_{b}\right) / \mathrm{E}_{\mathrm{L}}(\mathrm{Wh} / \mathrm{d}) \\
& =(5520 \times 0.8 \times 0.85) / 1511.52=2.48 \text { days }=59.6 \mathrm{~h}
\end{aligned}
$$

\subsubsection{Charge Regulator}

Charge regulators (controllers) are rated based on the amount of amperage they can process from a solar array. If a controller is rated at 20 amps it means that you can connect up to 20 amps of solar panel output current to this controller. A suitable charge regulator was used in the PV-RO system with the specification of $12 \mathrm{~V} / 24 \mathrm{~V}$, $20 \mathrm{~A}$.

\section{Results and Discussion}

\subsection{Metrological Data}

Average values of solar irradiation $\left(\mathrm{W} / \mathrm{m}^{2}\right)$, insolation $\left(\mathrm{kWh} / \mathrm{m}^{2} / \mathrm{d}\right)$, and ambient temperature $\left({ }^{\circ} \mathrm{C}\right)$ were recorded for different months during the year 2007 and presented in Table 1. As shown, the month of September was the hottest $\left(26^{\circ} \mathrm{C}\right)$ with the highest solar insolation $\left(7.5 \mathrm{kWh} / \mathrm{m}^{2} / \mathrm{d}\right)$.

The RO unit was designed to operate $24 \mathrm{~h} /$ day. The energy required was supplied by a PV array and battery storage was used to power the unit during the low solar intensity periods. The generated energy form the PV array varied in accordance with variations in the environmental conditions (insolation and ambient temperature). These variations affected the amount of daily produced water.

The average daily generated energy was calculated during different months depending on the peak power of the PV array $\left(P_{\text {peak }}\right)$, average daily peak sunshine hours (PSSH), battery efficiency factor $\left(\eta_{b}\right)$, and the PV array thermal factor $\left(\eta_{t h}\right)$, and can be determined as follows:

$$
\mathrm{E}_{\text {generated }}=\mathrm{P}_{\text {peak }} \times \mathrm{PSSH} \times \eta_{t h} \times \eta_{b}
$$

Using the above equation, a comparison was made between the average daily generated energy during months and that required by the load to operate the system for 24 h daily as shown in Figure 3.

As shown in Figure $\mathbf{3}$ the energy generated during summer months exceeds that required by the system (excluding the softener and feed pump) by about $40 \%$. The energy generated varies from month to month depending mainly on the sky if sunny or cloudy.

\subsection{System Performance}

The solar irradiation and the ambient temperature had a significant influence on the performance of the PV system. As irradiation increases, the PV current increases significantly due to high energy absorbed by the PV modules. It increased by $46 \%$ when the irradiation increased by $52 \%$ as illustrated in Table 2 . The power output follows the behavior of the modules current and increases as irradiation increases. Slight variation in the PV voltage was observed when the irradiation increased.

Table 1. Monthly average values for insolation, irradiation, and ambient temperature.

\begin{tabular}{cccccc}
\hline Month & $\begin{array}{c}\text { Insolation } \\
\left(\mathbf{k W h} / \mathbf{m}^{\mathbf{2}} / \mathbf{d}\right)\end{array}$ & $\begin{array}{c}\text { Irrad. } \\
\mathbf{( W / \mathbf { m } ^ { 2 } )}\end{array}$ & $\begin{array}{c}\text { Ambient Temperature }\left({ }^{\circ} \mathbf{C}\right) \\
\text { Av. Max. Min. }\end{array}$ \\
\hline Sep, 07 & 7.5 & 595.4 & 26 & 40 & 18 \\
Oct, 07 & 6.65 & 564.3 & 24 & 39 & 14 \\
Nov, 07 & 5.3 & 485.4 & 17 & 33 & 6 \\
Dec, 07 & 4.8 & 457.3 & 11.5 & 23 & 1.7 \\
Jan, 08 & 4.7 & 442.2 & 7 & 19.3 & 0 \\
Feb, 08 & 5.5 & 480 & 10.6 & 27.6 & 1.4 \\
Mar, 08 & 6.6 & 531 & 18.6 & 37.7 & 5.1 \\
\hline
\end{tabular}




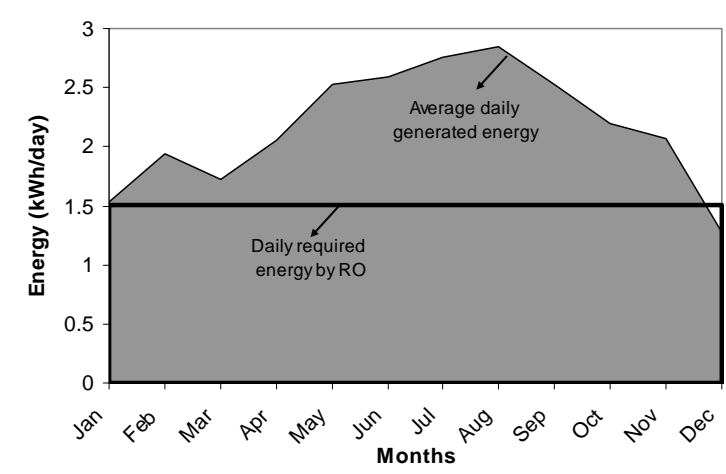

Figure 3. The average daily generated energy versus the required by the $\mathrm{RO}$ unit at different months.

Table 2. The effect of irradiation on the power output.

\begin{tabular}{cccc}
\hline $\begin{array}{c}\text { Irradiation } \\
\left(\mathbf{W} / \mathbf{m}^{2}\right)\end{array}$ & $\begin{array}{c}\text { Module Ampere } \\
\text { (A) }\end{array}$ & $\begin{array}{c}\text { Array Ampere } \\
(\mathbf{A})\end{array}$ & Array Power (W) \\
\hline 0 & 0 & 0 & 0.0 \\
200 & 0.75 & 3 & 104.4 \\
400 & 1.25 & 5 & 174.0 \\
600 & 2 & 8 & 278.4 \\
800 & 2.6 & 10.4 & 361.9 \\
1000 & 3.11 & 12.44 & 432.9 \\
\hline
\end{tabular}

\subsubsection{Specific Energy Consumption}

The theoretical specific energy consumption (SEC) for the PV-RO system was determined as follows:

SEC $\left(\mathrm{kWh} / \mathrm{m}^{3}\right)=$ Input Power * Opr. hours/Daily produced flow

Input power $=$ softener pump power + intake pump power

$$
\begin{aligned}
& + \text { high pressure pump power } \\
& =746+60+57.6=863.6 \mathrm{~W} \\
\mathrm{SEC} & =13.82 \mathrm{kWh} / \mathrm{m}^{3}
\end{aligned}
$$

With the softener the SEC was $13.82 \mathrm{kWh} / \mathrm{m}^{3}$ but was $1.9 \mathrm{kWh} / \mathrm{m}^{3}$ without it.

\subsubsection{System Results}

At an operating pressure of 4.5 bar, the average feed flow was $99 \mathrm{~L} / \mathrm{h}$ and the permeate flow was around $34 \mathrm{~L} / \mathrm{h}$ (34\% permeate recovery). Operating the system for three hours produced $119 \mathrm{~L}$ of permeate as shown in Figure 4.

The effect of feed temperature on both of recovery and salt rejection are illustrated in Figures $\mathbf{5}$ and $\mathbf{6}$, respectively. The percentage of recovery increased from $30 \%$ to $38 \%$ when feed water temperature increased from $12.4^{\circ} \mathrm{C}$ to $21.2{ }^{\circ} \mathrm{C}$, and the rejection of salts decreased from $98 \%$ to $97.4 \%$ when feed water temperature increased from $13.8^{\circ} \mathrm{C}$ to $21.4^{\circ} \mathrm{C}$.

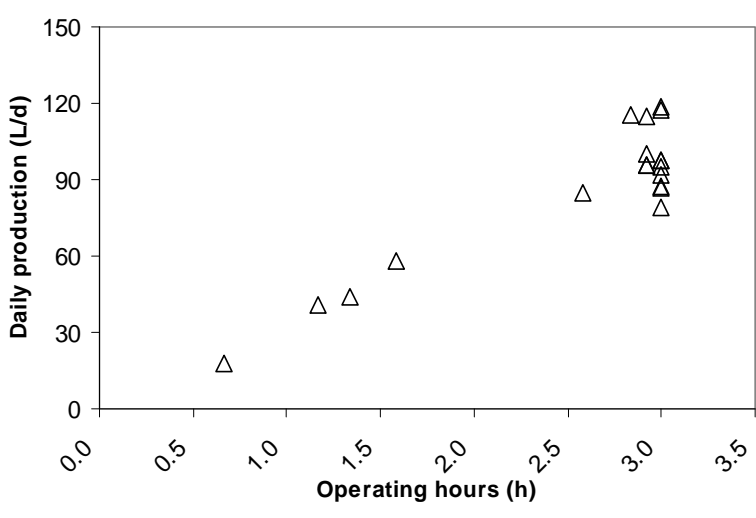

Figure 4. Daily production as a function of operating hours (operating pressure $=4.5$ bar).

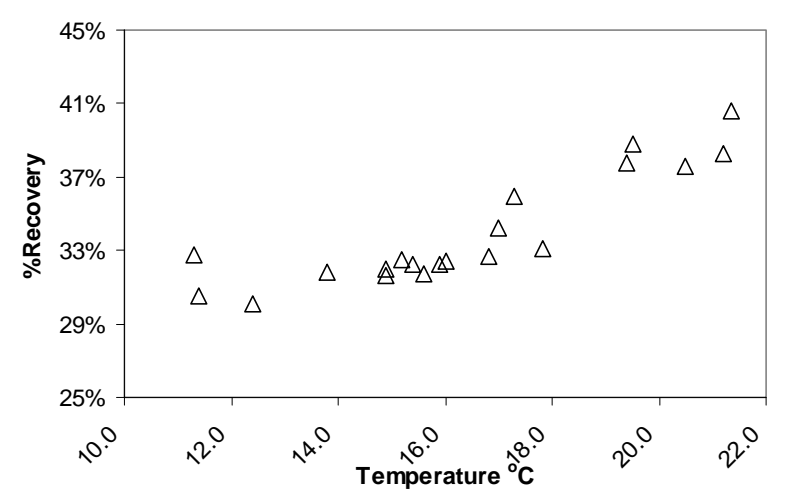

Figure 5. Percentage recovery as a function of feed temperature (operating pressure $=4.5$ bar).

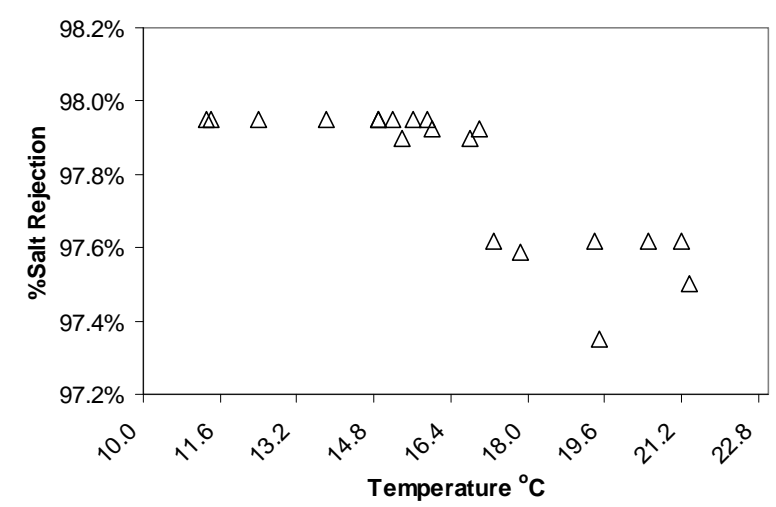

Figure 6. Percentage of salt rejection as a function of feed temperature (operating pressure $=4.5$ bar).

At an operating pressure of 4.5 bar, the average feed flow was $99 \mathrm{~L} / \mathrm{h}$ and the permeate flow was around 34 $\mathrm{L} / \mathrm{h}$ (34\% permeate recovery). Operating the system for three hours produced $119 \mathrm{~L}$ of permeate as shown in Figure 4.

The effect of feed temperature on both of recovery and salt rejection are illustrated in Figures 5 and 6, respectively. The percentage of recovery increased from $30 \%$ to 
$38 \%$ when feed water temperature increased from $12.4^{\circ} \mathrm{C}$ to $21.2^{\circ} \mathrm{C}$, and the rejection of salts decreased from $98 \%$ to $97.4 \%$ when feed water temperature increased from $13.8^{\circ} \mathrm{C}$ to $21.4^{\circ} \mathrm{C}$.

The recovery percentage affected salt passage through the membrane. In fact, the increase in recovery was associated with a decrease in salt rejection. For example, as the recovery percentage increased from $30 \%$ to $40 \%$, the salt rejection decreased from $98 \%$ to $97.5 \%$.

The average specific energy consumption (SEC) was about $26 \mathrm{kWh} / \mathrm{m}^{3}$ at an operating pressure of 4.5 . The SEC reached $19.4 \mathrm{kWh} / \mathrm{m}^{3}$ for a recovery percentage of $40.6 \%$ and reached $32 \mathrm{kWh} / \mathrm{m}^{3}$ for $30 \%$ of recovery as shown in Figure 7.

\section{Conclusions}

Design and sizing of the PV-RO unit components was presented. The main conclusions of this work are:

1) The percentage recovery was temperature dependent and increased from 29 to $41 \%$ when temperature was increased from $11^{\circ} \mathrm{C}$ to $22^{\circ} \mathrm{C}$. However, the salt reject slightly decreased with temperature increase.

2) The actual specific energy consumption depended on recovery percentage and was in the range of 19 to 32 $\mathrm{kWh} / \mathrm{m}^{3}$.

3) Installing the softener before the RO unit to pretreat brackish water solved the problem of scaling.

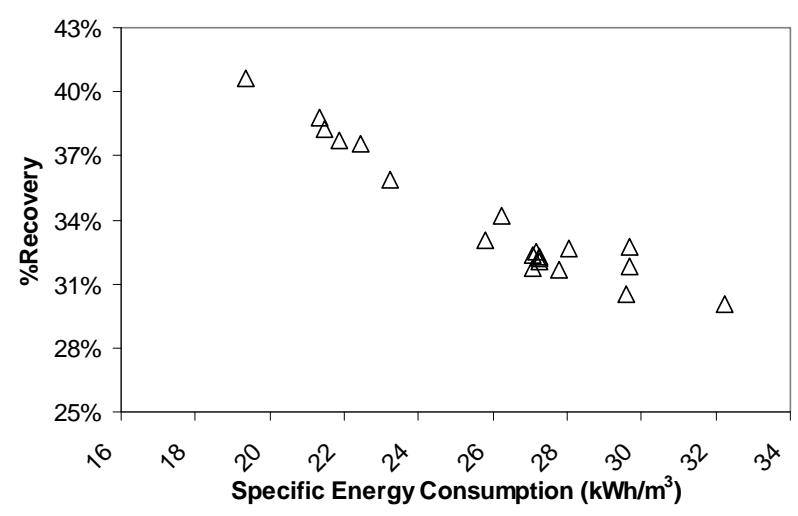

Figure 7. The relation between recovery percentage and the specific energy consumption (operating pressure $=4.5$ bar).

\section{Acknowledgements}

This work was supported by funds from the European Union through the ADIRA project. Financial support from the Petroleum Institute in Abu Dhabi to publish the work is gratefully acknowledged.

\section{REFERENCES}

[1] L. Garcia-Rodriguez, "Renewable Energy Applications in Desalination: State of the Art," Solar Energy, Vol. 75, No. 5, 2003, pp. 381-393. doi:10.1016/j.solener.2003.08.005

[2] D. Herold and A. Neskakis, "A Small PV-Driven Reverse Osmosis Desalination Plant on the Island of Gran Canaria,” Desalination, Vol. 137, No. 1-3, 2001, pp. 285292. doi:10.1016/S0011-9164(01)00230-2

[3] Energy Research Institute of King Abdulaziz City for Science and Technology, "Photovoltaic Water Pumping and Desalination at Sadous Village," Newsletter of The Middle East Desalination Research Center, Saudi Arabia.

[4] K. Mathew, S. Dallas, G. Ho and M. Anda, "Innovative Solar Powered Village Potable Water Supply,” Proceedings of Women Leaders on the Uptake of Renewable Energy Seminar, Perth, 2001.

[5] P. Carvalho, D. Riffel, C. Freire and F. Montenegro, “The Brazilian Experience with a Photovoltaic Powered Reverse Osmosis Plant,” Progress in Photovoltaics, Vol. 12, No. 5, 2004, pp. 373-385. doi:10.1002/pip.543

[6] D. Riffel and P. Carvalho, "Small-Scale PhotovoltaicPowered Reverse Osmosis Plant without Batteries: Design and Simulation,” Desalination, Vol. 247, No. 1-3, 2009, pp. 378-389. doi:10.1016/j.desal.2008.07.019

[7] E. Mohamed, G. Papadakis, E. Mathioulakis and V. Belessiotis, "The Effect of Hydraulic Energy Recovery in a Small Sea Water Reverse Osmosis Desalination System; Experimental and Economical Evaluation,” Desalination, Vol. 184, No. 1-3, 2005, pp. 241-246. doi:10.1016/j.desal.2005.02.066

[8] H. Qiblawey, F. Banat and Q. Al-Nasser, "Laboratory Setup for Water Purification Using Household PV-Driven Reverse Osmosis Unit," Desalination and Water Treatment, Vol. 7, No. 3, 2009, pp. 53-59. doi:10.5004/dwt.2009.695

[9] G. Ahmad and J. Schmidt, "Feasibility Study of Brackish Water Desalination in the Egyptian Deserts and rural Regions Using PV Systems,” Energy Conversion and Management, Vol. 43, No. 18, 2002, pp. 2641-2649. doi:10.1016/S0196-8904(01)00189-3 